\title{
KESTABILAN PENYETARAAN VERTIKAL DENGAN METODE EKUIPERSENTIL BERDASARKAN PROPORSI KELOMPOK GANDENG
}

\author{
Eva Puspita Dewi \\ Universitas Negeri Jakarta
}

\section{Wardani Rahayu}

Gaguk Margono

Universitas Negeri Jakarta

\begin{abstract}
The purpose of this research is to know: Accuracy of vertical equating with equipercentil method for proportion of 10\%, 20\%, and 30\% anchor group; The research method used is the experimental method with the independent variable is the proportion of the anchor group and the dependent variable is the accuracy of vertical equating by equipercentil method expressed by Root Mean Square Difference (RMSD) obtained from 40 replication. The research data obtained from the score of mathematics learning test for the topic of counting operations on integers and fractions in class VI and class VII $2^{\text {nd }}$ semester academic year 2016/2017. The results showed that the accuracy of vertical equalization of the equipersentil method with the proportion of the anchor group $20 \%$ more accurate than the proportion of the anchor group $10 \%$ and $30 \%$.
\end{abstract}

\section{Keywords}

vertical equating, equipersentil method, anchor group

\begin{abstract}
ABSTRAK
Tujuan penelitian ini untuk mengetahui: Keakurasian penyetaraan vertikal dengan metode ekuipersentil untuk proporsi kelompok gandeng $10 \%, 20 \%$, dan $30 \%$. Metode penelitian yang digunakan adalah metode eksperimen dengan variabel bebas adalah proporsi kelompok gandeng dan variabel terikatnya adalah keakurasian penyetaraan vertikal dengan metode ekuipersentil yang dinyatakan dengan Root Mean Square Difference (RMSD) yang diperoleh dari 40 replikasi. Data penelitian diperoleh dari sekor tes hasil belajar Matematika untuk topik operasi hitung pada bilangan bulat dan pecahan di kelas VI dan kelas VII semester 2 tahun ajaran 2016/2017. Hasil penelitian menunjukkan keakurasian penyetaraan vertikal metode ekuipersentil dengan proporsi kelompok gandeng $20 \%$ lebih akurat dibandingkan dengan proporsi kelompok gandeng $10 \%$ dan $30 \%$.
\end{abstract}

\section{Kata Kunci}

Penyetaraan Vertikal, Metode Ekuipersentil, Kelompok Gandeng e-mail:

evapuspitadewi01@gmail.com setiap jenjang kelas pada suatu jenjang pendidikan agar perkembangan atau perubahan tingkat kemampuan siswa dapat diukur. Untuk mengetahui kemampuan berpikir aktual dari peserta didik dengan jenjang kelas berbeda dikembangkan dua alat tes yang berbeda akan tetapi mengukur kemampuan yang sama. Permasalahan muncul, apakah sekor yang diperoleh setara dan dapat diperbandingkan karena berasal dari dua kelompok yang berbeda. Untuk itu maka sekor yang diperoleh harus disetarakan.

Penyetaraan dapat dilakukan secara vertikal. Penyetaraan vertikal melibatkan dua atau lebih instrumen tes yang mengukur kemampuan yang sama, dengan distribusi kemampuan peserta berbeda, peserta tes berasal dari level kelas yang berbeda. Penyetaraan vertikal dapat digunakan 
guru untuk mengungkap perkembangan kemampuan peserta didik walaupun peserta didik tersebut berada pada tingkat kelas yang berbeda dan memiliki tingkat kemampuan berbeda, asalkan tes yang digunakan mengukur kemampuan (trait) yang sama (Patz \& Yao, 2007). Penyetaraan vertikal biasanya diaplikasikan pada mata pelajaran yang bersifat penalaran, bukan hafalan (Zhu, 1998).

Untuk memperoleh hasil penyetaraan yang akurat maka perlu diperhatikan pemilihan metode, desain (Kolen \& Brennan, 1995). Selain pemilihan metode dan desain yang tepat, nilai kesalahan pengukuran yang dinyatakan dalam Root Mean Square Difference (RMSD) merupakan salah satu indikator keakurasian suatu penyetaraan.

Penyetaraan sekor secara klasik memiliki dua metode yaitu linier dan ekuipersentil. Pada penyetaraan ekuipersentil, peringkat persentil dari sekor asal disamakan dengan peringkat persentil sekor hasil penyetaraannya sehingga hubungan mereka pada umumnya menjadi nonlinier. metode penyetaraan adalah suatu cara mencari hubungan antara dua sekor tes dari dua instrumen yang berbeda dengan menggunakan statistik tertentu, dan pengumpulan datanya dilakukan dengan desain/rancangan pengumpulan data tertentu.

Adapun desain penyetaraan yang digunakan adalah rancangan $C$ (Naga, 20l3). Pada rancangan C, kelompok $\mathrm{KI}$ mengikuti ujian dengan instrumen $X$ dan kelompok $\mathrm{K} 2$ mengerjakan instrumen $Y$, sedangkan kelompok gandeng (KG) yaitu kelompok yang terdiri dari sebagian kelompok $\mathrm{KI}$ dan sebagian kelompok K2 yang bersama-sama mengerjakan instrumen $\mathrm{X}$ dan $\mathrm{Y}$.

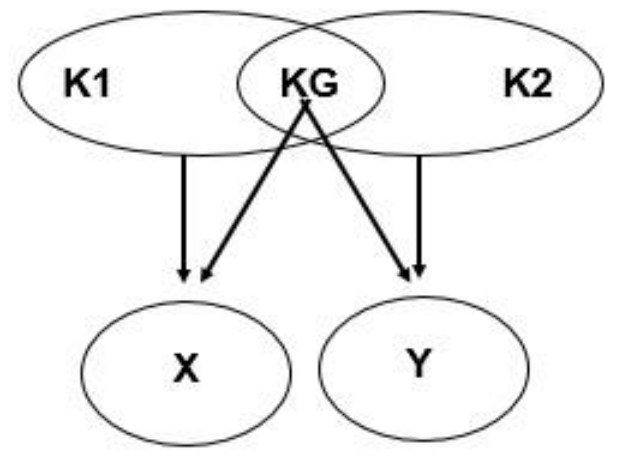

Gambar I. Kelompok Gandeng internal
Pada desain penyetaraan dikenal butir gandeng dan kelompok gandeng (Naga, 20l3). Penelitian sebelumnya yang berkaitan dengan proporsi butir gandeng dalam penyetaraan adalah Kolen dan Brennan (1995) yang menyatakan makin banyak proporsi butir gandeng untuk model tes dikotomi minimal $20 \%$ dari 40 butir soal atau lebih. Selain itu menurut Crocker dan Algina (2008) jumlah butir gandeng sekurang-kurangnya 20\% dari jumlah total tes. Adapun Sugeng (2010) dalam penelitiannya menyatakan bahwa banyaknya butir tes gandeng berpengaruh terhadap kualitas penyetaraan vertikal model kredit parsial. Keakurasian penyetaraan makin baik seiring dengan bertambahnya soal atau butir gandeng. Sedangkan menurut Yetti Supriyati, Ade Liyana, dan Wardani Rahayu (2016) keakurasian penyetaraan vertikal metode ekuipersentil dengan panjang tes 25 lebih rendah daripada keakurasian penyetaraan vertikal metode ekuipersentil dengan panjang tes 30 untuk ukuran sampel 100 dan 200 .

Penelitian sebelumnya banyak mengkaji tentang hubungan proporsi butir gandeng terhadap keakurasian penyetaraan, akan tetapi belum ada penelitian yang mengkaji hubungan kelompok gandeng dengan keakurasian penyetaraan vertikal. Maka tujuan penelitian ini adalah untuk mengetahui keakurasian penyetaraan vertikal dengan metode ekuipersentil untuk proporsi kelompok gandeng $10 \%, 20 \%$, dan $30 \%$.

\section{Metode Penelitian}

Penelitian ini mengunakan metode eksperimen. Dengan variabel bebas proporsi kelompok gandeng (10\%, $20 \%$, dan $30 \%)$, variabel terikatnya keakurasian penyetaraan vertikal dengan metode ekuipersentil.

Prosedur dalam melakukan penelitian ini dimulai dengan penentuan standar kompetensi lulusan (SKL), standar kompetensi, kompetensi dasar, dan indikator yang akan dikembangkan menjadi kisi-kisi soal. Kemudian, uji validitas isi dan keterbacaan soal oleh pakar dalam bidang matematika dan pengukuran guna menilai kesesuaian butir soal dengan indikator dan ketepatan penggunaan bahasa dalam butir soal. Setalah direvisi oleh pakar kemudian dilakukan uji coba instrumen untuk kemudian dihitung nilai 
validitas (point biserial) dan reliabilitas butir tes (KR-20) yang disusun. Butir-butir yang valid kemudian diseleksi untuk dirakit menjadi tes hasil belajar matematika yang digunakan sebagai instrumen pengumpulan data. Data yang telah dikumpulkan kemudian disetarakan dengan menggunakan metode ekuipersentil. Setelah diperoleh sekor setara, selanjutnya dihitung nilai RMSD untuk setiap replikasi yang kemudian dianalisis untuk keperluan pengujian hipotesis penelitian. Adapun rumus untuk menghitung RMSD adalah sebagai berikut:

$$
R M S D=\sqrt{\frac{\sum_{j=1}^{n}\left(\bar{\theta}_{i}-\theta_{i}\right)^{2}}{N}}
$$

Keterangan:

$\mathrm{N} \quad=$ ukuran sampel

$\bar{\theta}_{\bar{i}} \quad=$ sekor peserta ke i setelah disetarakan

$\theta_{i} \quad=$ sekor peserta ke i sebelum disetarakan

Uji hipotesis penelitian yang digunakan adalah teknik analisis statistik one way anova kemudian dilanjutkan dengan uji lanjut t-dunnett. Namun, sebelum dilakukan uji one way anova terlebih dahulu dilakukan uji prasyarat analisis melalui uji normalitas dan homogenitas data.

Karena setiap data normal dan homogen maka untuk pengujian hipotesis selanjutnya dapat dilakukan dengan uji statistika parametrik one way anova dengan menggunakan SPSS 16.0. kesimpulan dari uji one way anova bahwa terdapat perbedaan nilai RMSD antara ketiga hasil penyetaraan ekuipersentil yang menggunakan proporsi kelompok gandeng 10\%, 20\%, dan 30\%. Sehingga, untuk mengetahui proporsi mana di antara dua kelompok sampel yang berbeda secara signifikan, dilakukan uji lanjut atau post hoc test dengan menggunakan uji $t$-dunnett.

Rumus untuk menentukan $\mathrm{t}$ hitung (dunnett) adalah sebagai berikut:

$$
T \text { hitung }=\frac{\left|\bar{Y} i-\overline{Y_{j}}\right|}{\sqrt{R J K(D)\left(\frac{1}{n_{i}}+\frac{1}{n_{2}}\right)}}
$$

Instrumen penelitian yang digunakan berupa tes formatif mengenai operasi hitung aljabar pada bilangan bulat dan pecahan. Tes terdiri dari 25 butir soal pilihan ganda dengan 4 pilihan jawaban.

Populasi yang digunakan pada penelitian ini adalah siswa SMP dan SD Tahun Ajaran 2016/2017 di Kota Sukabumi. Dari populasi ini diambil sampel untuk 2 (dua) level kelas yang berbeda, yaitu: kelas VI dan VII dengan teknik Stratified Random Sampling. Sampel yang mewakili adalah SMPN I Sukabumi, SMPN 2 Sukabumi, SDN CBM Dewi Sartika, SDN CBM Pakujajar, SDN CBM Suryakencana dengan jumlah 200 orang tiap sekolah.

\section{Hasil Penelitian dan Pembahasan}

Data diperoleh dari pemberian tes hasil belajar siswa kelas VI dan VII untuk topik operasi bilangan bulat dan pecahan. Kemudian data disetarakan menggunakan metode ekuipersentil dilanjutkan dengan menghitung nilai RMSD.

Untuk setiap pengacakan diperoleh rata-rata RMSD untuk masing-masing proporsi adalah sebagai berikut:

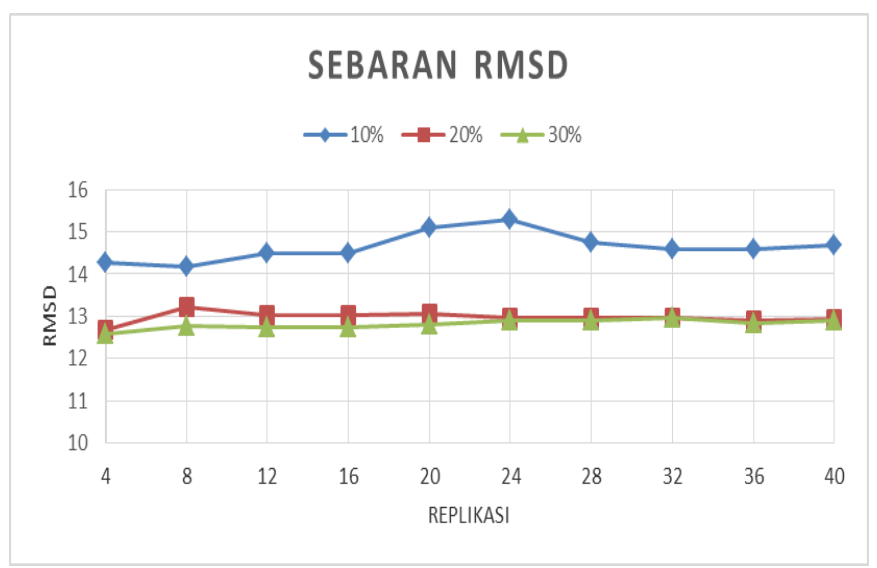

Perbandingan nilai rata-rata RMSD untuk proporsi kelompok gandeng 30\% dari replikasi ke-4 sampai dengan replikasi ke-24 menunjukkan nilai rata-rata terkecil dibandingkan dengan nilai rata-rata RMSD untuk proporsi $10 \%$ dan $20 \%$. Namun, setelah replikasi ke-24 sampai dengan replikasi ke-40 nilai rata-rata RMSD proporsi kelompok gandeng 20\% dan 30\% tidak terdapat perbedaan yang signifikan.

$$
\text { Dengan } t \text { tabel }=t(0,05: 117)=2.617
$$


Tabel I. Hasil pengujian hipotesis dengan uji lanjut $t$-dunnett.

\begin{tabular}{lccc}
\hline Hipotesis statistik & $\mathrm{T}_{\text {hitung }}$ & $\mathrm{T}_{\text {tabel }}$ & Kesimpulan \\
\hline $\mathrm{H}_{0}: \mu_{10 \% 6} \leq \mu_{20 \%}$ & 3.729 & 2.617 & Tolak $\mathrm{H}_{0}$ \\
$\mathrm{H}_{1}: \mu_{10 \% 6}>\mu_{20 \%}$ & & & \\
\hline $\mathrm{H}_{0: \quad \mu_{10 \% 6} \leq \mu_{30 \%}} 3.798$ & 2.617 & Tolak $\mathrm{H}_{0}$ \\
$\mathrm{H}_{1}: \mu_{30 \% 6}>\mu_{10 \%}$ & & & \\
\hline $\mathrm{H}_{0}: \mu_{20 \% 6} \leq \mu_{30 \% 6}$ & 0.068 & 2.617 & Terima $\mathrm{H}_{0}$ \\
$\mathrm{H}_{1}: \mu_{20 \% 6}>\mu_{30 \% 6}$ & & & \\
\hline
\end{tabular}

Hasil uji lanjut menunjukkan bahwa rata-rata nilai RMSD untuk proporsi $20 \%$ lebih kecil dari rata-rata RMSD untuk proporsi $10 \%$ dan $30 \%$. Sehingga untuk keakurasian tertinggi penyetaraan vertikal dengan metode ekuipersentil berada pada proporsi kelompok gandeng $20 \%$.

\section{Kesimpulan}

Berdasarkan hasil pengujian hipotesis, diperoleh kesimpulan sebagai berikut:

I. Keakurasian penyetaraan vertikal metode ekuipersentil dengan proporsi kelompok gandeng $20 \%$ lebih akurat dibandingkan dengan proporsi kelompok gandeng $10 \%$ dan $30 \%$.

2. Proporsi kelompok gandeng $20 \%$ menghasilkan keakurasian penyetaraan tertinggi.

\section{Daftar Pustaka}

Agung, I Gusti Ngurah. Statistika Penerapan Model Rerata-Sel Multivariat dan Model Ekonometri dengan SPSS. Jakarta: Yayasan SAD Satria Bhakti. 2006.

Antara, Anak Agung dan Bestari, "Penyetaraan Vertikal dengan Pendekatan Klasik dan Item Response Theory pada Siswa Sekolah Dasar". Jurnal Penelitian dan Evaluasi Pendidikan, Volume 19, No.1, 2015
Croker, Linda and James Algina. Introduction to Classical and Modern Test Theory. USA: Holt, Rinehart and Wiston. Inc. 1986.

Kolen, M. J. and Robert L. Brennan, Test Equating Methods and Practice. New York: Springer Verlag, 1995.

Mardapi, Djemari. Pengukuran, Penilaian dan Evaluasi Pendidikan. Yogyakarta: Nuha Medika. 2012.

Naga, Dali. S. Pengantar Teori Sekor pada Pengukuran Mental. Jakarta: PT. Nagarani Citrayasa. 20I3.

Patz, J. Richard and Lihua Yao, "Vertical Scaling: Statistical Models for Measuring Growth and Achievement". Handbook of Statistics, 2007.

Sugeng, "Penyetaraan Vertikal Model Kredit Parsial Soal Matematika SMP”. Jurnal Penelitian dan Evaluasi Pendidikan, 2010.

Supriyati, Yetti., Ade Liyana, and Wardani Rahayu. "Accuracy of Vertical Equating with Equipercentile method based on Sample Size and Test Lenghts". Proceeding 5 ISQAE UTY, 2016.

Zhu, Wiemo, "Test Equating: What, Why, How?". Research Quarterly for Exercise and Sport American Alliance for Health, Physical Education, Recreation and Dance, 1998. 